\title{
Retrograde Axonal Transport
}

\author{
A Possible Role in the Development of Neuropathy \\ P. Sidenius and J. Jakobsen \\ Second University Clinic of Internal Medicine, Institute of Pathology, and Department of Cell Biology, Institute of Anatomy, \\ University of Aarhus, Aarhus, Denmark
}

Summary. The accumulation of ${ }^{3} \mathrm{H}$-fucose labelled glycoprotein and ${ }^{35} \mathrm{~S}$-methionine labelled protein carried by the retrograde axonal transport in the sensory fibres of the sciatic nerve was examined on the day after injection of streptozotocin in rats. The accumulation of fucose-label was reduced $(2.8 \pm 0.4$ (SD) versus $2.1 \pm 0.5$ (arbitrary units), $2 \mathrm{p}=0.0044$ ) indicating a decreased retrograde flux of glycoproteins. This early transport abnormality could have a key role in the development of peripheral neuropathy in diabetes.

Key words: Axonal transport, diabetic neuropathies, streptozotocin diabetes, nerve crush

In the nerve cell proteins associated with structure and transmitter function are synthesised in the cell body and subsequently carried by the anterograde transport system to the axon and its terminals. In the opposite direction there is a retrograde transport of macromolecules suggested to act as a messenger safeguarding the integrity of the entire neuron [16].

Abnormalities in the axonal transport of macromolecules could underlie the development of fibre degeneration and functional impairment in axonopathies. Studies to examine this hypothesis are, however, few and inconclusive $[4,7,8,19-22]$.

We have earlier shown that reduced myelinated fibre calibre $[9,10]$ and reduced nerve conduction velocity [11] are associated with a decreased flux of retrogradely transported glycoproteins in intact [12] and crushed [26] nerves of streptozotocin rats four weeks after the induction of diabetes. This transport abnormality could be an early and important feature in the development of diabetic neuropathy but it might as well be a late consequence of changes in morphology. In an attempt to clarify this question we now report on retrograde axonal transport of glycoproteins at the earliest possible interval after the induction of diabetes in the animal model.

\section{Methods}

Male Wistar rats 25 weeks old weighing between 305 and $445 \mathrm{~g}$ were injected IV with $40 \mathrm{mg} \mathrm{kg}^{-1}$ streptozotocin dissolved in $0.15 \mathrm{~mol} / 1$ saline $(\mathrm{pH} 4.8)$. Blood glucose was measured in nonfasting animals at $2-8 \mathrm{~h}$ intervals with Dextrostix and an Ames Reflectancemeter.

On the following day at a time when the blood glucose level had reached a plateau (Fig. 2) the diabetic rats and their age and weight matched controls were injected with $1 \mu$ of a buffered [18] precursor solution containing $5 \mu \mathrm{Ci}{ }^{35} \mathrm{~S}$-methionine $(750 \mathrm{Ci}$ $\mathrm{mmol}^{-1}$, Amersham) and $10 \mu \mathrm{Ci}{ }^{3} \mathrm{H}$-fucose $\left(26 \mathrm{Ci} \mathrm{mmol}^{-1}\right.$, Amersham) in each microlitre into the right fifth lumbar dorsal root ganglion [24]. Twelve hours later the left ganglia were injected with $1 \mu \mathrm{l}$ of the same precursor solution and subsequently a crush was produced in the distal part of the left sciatic nerve just above the knee [26].

Nineteen hours after injection into the right ganglia and $7 \mathrm{~h}$ after the injection on the left side two collection ligatures $6 \mathrm{~mm}$ apart were placed for a $2 \mathrm{~h}$ period in the midthigh portion of the sciatic nerve on both sides $[2,3]$. At the end of the collection period the nerves were removed and axonal transport stopped by cooling. The frozen nerves were cut into 3 or $6 \mathrm{~mm}$ segments as shown in Figure 1. Eventually, the segments were treated with $10 \%$ TCA (trichloroacetic acid, w/w), dissolved in Lumasolve and their activity measured by liquid scintillation counting.

The flux of activity carried by the retrograde and the anterograde axonal transport were estimated by the accumulation proximal to the proximal ligature and distal to the distal one, respectively [12].

Student's t-test was employed for the statistical analysis using a $5 \%$ limit of significance.

\section{Results}

In Figure 2 mean blood glucose values measured at 2-8 $\mathrm{h}$ intervals for the $50 \mathrm{~h}$ experimental period are shown. During the first day an initial lag period of 5-10 h was followed by a steady increase in the glucose level. On the second day the level plateaued with individual values varying between 14.4 and $23.9 \mathrm{mmol} 1^{-1}$.

Table 1 shows the data for the retrograde and the anterograde flux of labelled material obtained during the second day of the experiment.

The retrograde flux of glycoprotein activity in intact nerves was decreased by $25 \%$ whereas the flux 
Table 1. Retrograde and anterograde axonal flux of ${ }^{35} \mathrm{~S}$-methionine labelled protein and ${ }^{3} \mathrm{H}$-fucose labelled glycoproteins in intact and crushed nerves for diabetic rats and controls. Values are means \pm SD (n)

\begin{tabular}{|c|c|c|c|c|c|}
\hline \multirow[t]{4}{*}{ Substance } & \multirow[t]{4}{*}{ Group } & \multicolumn{4}{|l|}{ Axonal flux } \\
\hline & & \multicolumn{2}{|c|}{ Intact nerve (19-21 h after precursor injection) } & \multicolumn{2}{|c|}{ Crushed nerve ( $7-9 \mathrm{~h}$ after precursor injection) } \\
\hline & & Retrograde & Anterograde & Retrograde & Anterograde \\
\hline & & \multicolumn{4}{|c|}{ (pre-existing activity) $\mathrm{mm}^{\mathrm{h}^{-1}}[12,26]$} \\
\hline${ }^{35} \mathrm{~S}$-methionine & Control & $1.3 \pm 0.4(10)$ & $1.9 \pm 0.6(10)$ & $3.6 \pm 0.3(10)$ & $2.8 \pm 0.5(10)$ \\
\hline labelled & Diabetes & $1.1 \pm 0.2(8)$ & $2.3 \pm 0.1(8)$ & $3.1 \pm 0.6(9)$ & $3.7 \pm 0.8(9)$ \\
\hline protein & $2 \mathrm{P}$ & NS & NS & 0.040 & 0.0093 \\
\hline${ }^{3} \mathrm{H}$-fucose & Control & $2.8 \pm 0.4(9)$ & $3.9 \pm 1.0(9)$ & $3.2 \pm 0.4(10)$ & $5.0 \pm 0.9(10)$ \\
\hline labelled & Diabetes & $2.1 \pm 0.5(8)$ & $4.1 \pm 0.6(8)$ & $2.3 \pm 0.7(9)$ & $5.9 \pm 0.9(9)$ \\
\hline glycoprotein & $2 P$ & 0.0044 & NS & 0.0015 & 0.048 \\
\hline
\end{tabular}



Fig. 1. The figure shows the placing of the two collection ligatures ( $6 \mathrm{~mm}$ apart) on the intact nerve on the right side and on the crushed nerve on the left. Formulae for calculation of the retrograde (DA) and the anterograde accumulation (PA) are given. $\left(A_{d}\right)$ activity in distal accumulation segment, $\left(A_{p}\right)$ activity in proximal accumulation segment, $\left(S_{i}\right)$ activity in interligature segment and $\left(S_{d}\right)$ and $\left(S_{p}\right)$ activity in distal and proximal segments

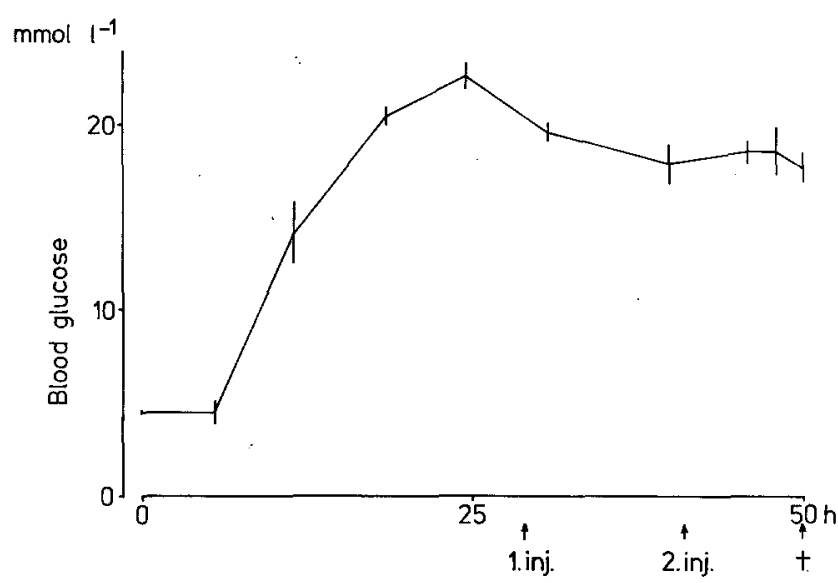

Time after streptozotocin injection

Fig. 2. Blood glucose values as a function of time after intravenous injection of streptozotocin in nine test rats. Values are group means and SEM's. The time for the first and the second dorsal root ganglion injection and time for the end of the experiment are indicated on the abscissa

of labelled protein was statistically unchanged. In crushed nerves the retrograde flux of both labels was decreased, glycoproteins twice as much as proteins. The anterograde flux in intact nerves was normal. In crushed nerves it was increased for both labels.

\section{Discussion}

The present experiment has demonstrated that the abnormality in axonal accumulation of retrogradely transported glycoproteins is present at a very early time after treatment with streptozotocin, namely, a few hours after the establishment of a persistent hyperglycaemic state.

It is not known whether morphological changes are present at that early time. In a previous study the myelinated nerve fibre calibre seemed to be gradually reduced during a 4 week period of streptozotocin diabetes whereas the density of axon organelles remained unchanged [11]. It is, therefore, likely that the very early changes in axonal glycoprotein flux precede the abnormalities in fibre structure.

The present observation taken in concert with previous findings enable us to suggest that the decreased retrograde flux of glycoproteins induces the reset of the protein synthesis in the nerve cell body necessary for the decrease of anterograde transport of structural proteins [13]. The morphological consequence of these protein abnormalities could be the reduction in size of the nerve cell body and its axon $[9,10,25]$.

The suggestion that information concerning the state of the axon and its terminals is communicated to the nerve cell body by the retrograde axonal transport is supported by the finding of an increased retrograde flux of proteins after nerve transsection [3], anticipating the associated biochemical and structural changes in the nerve cell body $[1,6,14$, 15]. Since the increase in the retrograde flux is accompanied by an increased anterograde transport of structural proteins in regenerating nerves after transsection [6] the changes in transport are reverse to those acting in streptozotocin diabetes. This leads us to suggest a key role for retrograde transport in nerve cells, increasing or decreasing, during various conditions. A general scheme for the way the nerve cell responds to changes in the physical and chemical surroundings is proposed as follows 
(1) nerve cell membrane changes

(2) retrograde axonal transport

(3) protein synthesis in the nerve cell body

(4) fast and slow anterograde axonal transport

(5) changes of structure and function of axons.

The chemical factor responsible for the development of diabetic neuropathy is likely to be glucose or one of its metabolites as rats fed galactose, an epimer of glucose, develop similar changes of the peripheral nerves as diabetic rats $[17,23,27]$.

Changes in the function of cell membranes in streptozotocin diabetes are indicated by the findings of a decreased activity of a cell membrane enzyme as well as of an abnormality of the pinocytotic vescicles $[5,28]$.

It is possible that the sequence of events as proposed for the pathological process in diabetic neuropathy applies to other axonopathies. Thus Sahenk and Mendell [22] found a decreased retrograde axonal flux in zinc pyridinethione neuropathy in rats a few weeks after the start of exposition to the drug. This change in axonal transport as well as those reported in other toxic axonopathies $[8,19,20]$ have all been demonstrated at a time when ultrastructural alterations are present in the axons. Consequently, it is not known whether these transport abnormalities are of a primary or a secondary nature.

At the moment it seems reasonable to suggest a key role for retrograde transport in the development of some of the axonopathies, for example diabetic neuropathy, the defect being misinformation for the direction of protein synthesis in the nerve cell body.

Acknowledgernents. We thank Inger Arensback Jensen and Helle Danvad Jensen for technical assistance and Anette Larsen for preparation of the manuscript. The work was supported, by the Danish Medical Research Council (512-15466) and by NOVO.

\section{References}

1. Aldskogius $H$ (1978) Fine structural changes in nerve cell bodies of adult rabbit dorsal motor vagal nucleus during axon reaction. Neuropathol Appl Neurobiol 4: 323-341

2. Bisby MA (1977) Retrograde axonal transport of endogenous protein: differences between motor and sensory axons. J Neurochem 28: 249-251

3. Bisby MA, Bulger VT (1977) Reversal of axonal transport at a nerve crush. J Neurochem 29: 313-320

4. Brimijoin S, Dyck PJ (1978) Axonal transport and peripheral nerve disease in man. In: Canal N, Pozza G (eds) Peripheral Neuropathies. Elsevier, Amsterdam, p 139-146

5. Clements RS, Stockard R (1980) Abnormal sciatic nerve myoinositol metabolism in the streptozotocin-diabetic rat. Diabetes 29: 227-235

6. Frizell M, Sjöstrand J (1974) The axonal transport of slowly migrating ${ }^{3} \mathrm{H}$-leucine labelled proteins and the regeneration rate in regenerating hypoglossal and vagus nerves of the rabbit. Brain Res 81: 267-283

7. Griffin JW, Price DL, Spencer PS (1977) Fast axonal transport through giant axonal swellings in hexacarbon neuropathy. $J$ Neuropathol Exp Neurol 36: 603

8. Griffin JW, Hoffman PN, Clark AW, Carroll PT, Price DL (1978) Slow axonal transport of neurofilament proteins: impairment by $\beta, \beta$ '-iminodipropionitrile administration. Science 202: 633-635

9. Jakobsen J (1976) Axonal dwindling in early experimental diabetes. I. A Study of cross sectioned nerves. Diabetologia 12: $539-546$

10. Jakobsen J (1976) Axonal dwindling in early experimental diabetes. II. A study of isolated nerve fibres. Diabetologia 12: 547-553

11. Jakobsen J (1979) Early and preventable changes of peripheral nerve structure and function in insulin-deficiency diabetic rat. J Neurol Neurosurg Psychiatry 42: 509-518

12. Jakobsen J, Sidenius P (1979) Decreased axonal flux of retrogradely transported glycoproteins in early experimental diabetes. J Neurochem 33: 1055-1060

13. Jakobsen J, Sidenius P (1980) Decreased axonal transport of structural proteins in streptozotocin diabetic rats. J Clin Invest 66: 292-297

14. Kessler JA, Black IB (1979) The role of axonal transport in the regulation of enzyme activity in sympathetic ganglia of adult rats. Brain Res 171: 415-424

15. Koenig HL (1965) Relations entre la distribution de l'activité acétylcholinestérasique et celle de l'ergastoplasme dans les neurones du ganglion ciliaire du poulet. Arch Anat Microsc Morphol Exp 54: 937-964

16. Krisstensson K, Olsson $Y$ (1973) Diffusion pathways and retrograde axonal transport of protein tracers in peripheral nerves. Prog Neurobiol 1: 87-109

17. Malmgren L, Jakobsen J, Olsson Y (1979) Permeability of blood-nerve barrier in galactose-fed rats. Exp Neurol 66: 758-770

18. Maude DL (1968) Stop-flow microperfusion of proximal tubules in rat kidney cortex slices. Am J Physiol 214: 1315-1321

19. Mendell JR, Sahenk Z, Saida K, Weiss HS, Savage R, Couri D (1977) Alterations of fast axoplasmic transport in experimental methyl n-butyl ketone neuropathy. Brain Res 133: 107-118

20. Rasool CG, Bradley WG (1978) Studies on axoplasmic transport of individual proteins: 1-acetylcholinesterase (AChE) in acrylamide neuropathy. J Neurochem 31: 419-425

21. Sahenk Z, Mendell JR (1979) Analysis of fast axoplasmic transport in nerve ligation and adriamycin-induced neuronal perikaryon lesions. Brain Res 171: 41-53

22. Sahenk Z, Mendell JR (1980) Axoplasmic transport in zinc pyridinethione neuropathy: evidence for an abnormality in distal turn-around. Brain Res 186: 343-353

23. Sharma AK, Thomas PK, Baker RWR (1976) Peripheral nerve abnormalities related to galactose administration in rats. J Neurol Neurosurg Psychiatry 39: 794-802

24. Sidenius P, Jakobsen J (1979) Axonal transport in early experimental diabetes. Brain Res 173: 315-330

25. Sidenius P, Jakobsen J (1980) Reduced perikaryal volume in lower motor and primary sensory neurons in early experimental diabetes. Diabetes 29: 182-186

26. Sidenius P, Jakobsen J (1980) Impaired retrograde axonal transport from a nerve crush in streptozotocin diabetic rats. Diabetologia 19: 222-228

27. Sidenius $\mathbf{P}$, Jakobsen $J$ (1980) Axonal transport in rats after galactose feeding. Diabetologia 19: 229-233

28. Østerby R, Gundersen HJG, Christensen NJ (1978) The acute effect of insulin on capillary endothelial cells. Diabetes 27: $745-749$

Received: April 28, 1980,

and in revised form: October 3, 1980

Per Sidenius

Anatomisk Institut

Universitetsparken

DK-8000 Aarhus C

Denmark 